DOI: 10.22559/folklor.852

folklor/edebiyat, cilt:25, sayı:98, 2019/2

\title{
Dânâ Ata Oğuznâmesi Hakkında Yapılan Çalışmalar ${ }^{1}$
}

\author{
Studies on Dânâ Ata Oğuznâma
}

\section{Ebru Birkan Akhan²}

Öz

Dânâ Ata Oğuznâmesi, Oğuznâmecilik geleneğinde adı zikredilen bir Oğuznâme'dir. Dânâ Ata Oğuznâmesi üzerine ilk çalışmayı A. N. Samoyloviç yapmıştır. Eser hakkında Türkmenistan'da Ahmed Bekmıradov'un çalıştığı görülmektedir. Bekmıradov'un ilim dünyasına tanıttığı Oğuznâme metni, Abdurrahman Mulkomanov ile gözden geçirilerek sunulmuştur. Türkiye'deki ilim adamlarının da Dânâ Ata Oğuznâmesi hakkında kısaca bilgi verdikleri tespit edilmiştir. Ayrıca Dânâ Ata'(İhsan Şeyh) nın kimliği üzerine de yeterli bilgi mevcut değildir. Bu sebepler, Dânâ Ata Oğuznâmesi üzerine çalışmaya sevk etmiştir. Dânâ Ata Oğuznâmesi'nin tıpkıbasım metni St. Petersburg İlimler Akademisi Doğu Bilimleri El Yazmaları Bölümü 1927-no 643'te, Samoyloviç'in bildirisinde yer almaktadır. Mezkûr bildiri için St. Petersburg İlimler Akademisi El Yazmaları Bölümü’ne gidilmiş̧tir.

Çalışmamız "Dânâ Ata Oğuznâmesi ve Oğuznâmecilik Geleneği” adlı Doktora Tezi üzerinedir. Elde edilen veriler doğrultusunda, A. N. Samoyloviç’e ait "Ebu'l Gazi Bahadır Han. Türkmenlerin Soy Ağacı Listelerinden Biri” adlı bildiriye Oğuznâmecilik Geleneği üzerine çalışan ilim adamlarının atıf yaptıkları görülmüş-

\footnotetext{
Bu çalışma, Dânâ Ata Oğuznâmesi ve Oğuznâmecilik Geleneği adlı Doktora Tezi’ nin altıncı bölümünden gözden geçirilerek oluşturulmuştur.

2 Dr. Öğr. Gör. Gazi Üniversitesi Sosyal Bilimler Enstitüsü Türk Dili ve Edebiyatı Ana Bilim Dalı. ebirkan@ selcuk.edu.tr
} 
tür. Dânâ Ata Oğuznâmesi'nin Hocalı Molla ile Oraz Muhammed Oğlu Molla Gurbangeldi olmak üzere iki yazıcısının olduğu anlaşılmıştır. Samoyloviç, Oğuznâme metninin Tumanskiy'e göre on altı bent sekiz heceli olduğunu belirtmiştir. Hece vezniyle yazılan manzum Oğuznâme'nin yazıya aktarılması sözlü gelenekte de icra edildiğini göstermektedir. Bu bağlamda Dânâ Ata ve Dânâ Ata Oğuznâmesi hakkında yapılan çalışmaların gün 1şığına çıkartılması amaçlanmıştır.

Anahtar sözcükler: Dânâ Ata, hece vezni, Oğuznâme, Samoyloviç, St. Petersburg, sözlü gelenek

\section{Abstract}

The Dânâ Ata Oğuznâma is an Oğuznâma mentioned in the tradition of Oğuznâmecilik. The first study on Dânâ Ata Oğuznâma was conducted by A.N. Samoylovich. It is seen that A. Bekmiradov studied about the work in Turkmenistan. The Oğuznâma text which is introduced to the science world by Bekmiradov was reviewed and presented by Abdurrahman Mulkomanov. It is determined also that the scientists in Turkey briefly gave information about Dânâ Ata Oğuznâma. Furthermore, any sufficient information is not available about the identity of Dânâ Ata (İhsan Şeyh). These reasons leaded to study on the Dânâ Ata Oğuznâma. Facsimile text of the Dânâ Ata Oğuznâma is included the communiqué of Samoylovich in the Oriental Manuscripts Department of the St. Petersburg Academy of Sciences in 1927 no-643.

Our study is about the doctorate study titled "Dânâ Ata Oğuznâma and the tradition of Oğuznâmecilik. In the direction of data obtained, it is seen that scientists studying on the tradition of Oğuznâmecilik referred to the paper titled "One of the Lists of Turkmen Family Tree, Ebu'l Gazi Bahadır Khan” belonging to A.N. Samoylovich. It is understood that there are two writers of the Dânâ Ata Oğuznâma who are Hocalı Molla and Molla Gurbangeldi son of Oraz Muhammed. Samoylovich stated that the texts of the Oğuznâma consisted of sixteen paragraphs and eight syllables. It reveals that writing the poetic Oğuznâma out that was written with syllabic meter was also performed in oral tradition. In this context, it is significant to bring the studies about Dânâ Ata and Dânâ Ata Oğuznâma to light.

Keywords: Dânâ Ata, syllabic meter, Oğuznâma, Samoylovich, St. Petersburg, oral tradition

\section{Giriş}

Dânâ A ta Oğuznâmesi üzerine çalışan araştırıcılar, Dânâ Ata adının Dânâ Ata Oğuznâmesi ${ }^{1}$ ile bağlantılı olduğunu düşünmüşlerdir. Demidov, Dânâ Ata' (Bilge Baba) nın “İhsan Şeyh" adıyla anıldığını ifade etmiştir (Демидов, 1990: 115).

Farsça sıfat Dânâ sözü “bilen, bilici, bilgiç” anlamlarına gelmektedir (Develioğlu, 1995: 164). Bu bağlamda, Oğuznâmecilik geleneğinde (Özkan, 1994) zikredilen Dede Korkut Kitabı'nın mukaddimesi düşündürücüdür. Şöyle ki:

"Resûl 'aleyhi's-selam zamanına yaḳın Bayat boyından Korḳut Ata dirler bir er ḳopdı. Oğuzuñ ol kişi tamam bilicisi-y-idi. Ne dir-se olur-idi. Gayıbdan dürlü haber söyler-idi. Hak Ta'āla anuñ köñline ilham ider-di ”(Ergin, 1997: 73). 
Türkmenler tarafından Dânâ Ata Oğuznamesi'nin (Birkan Akhan, 2107) müellifi olduğu belirtilen İhsan Şeyh'in Dede Korkut gibi devrinin bileni, bilici olması, onu, Oğuznâmelere bağlayan unsurlardan biridir. Bu cümleden Dânâ Ata yani İhsan Şeyh devrinin bileni, bilicisi olarak kabul edilmelidir. Mihály Hoppal'ın şaman kelimesinin anlamını “bilen, bilgiç” (Hoppal (Çev. Bayram-Çapraz), 2012: 21) şeklinde ifade etmesiyle ilişkili, Dânâ Ata'ya "İslami ortamda Ata kimliğine bürünmüş derviş" dememiz mümkündür. Dânâ Ata, Oğuznâme metninden anlaşıldığg üzere Hoca Ahmed Yesevî’ye bağlı bir Şeyh’tir:

"Pîrdür dirler babamızı

Nāme içre rāstdur sözi

İhsān Baba dirler bizi

Ebulhandur uranımız." (Самойлович,1927: 39-41).

Ahmed Bekmıradov, Dânâ Ata diğer adıyla İhsan Şeyh'in Dânâ Ata Oğuznâmesi'ni tertip ederek Ŏguzlara iyilik ve lütufta bulunduğu söylemiştir. Bu bağlamda, Dânâ adının ihsan kelimesiyle de örtüştüğü görülmektedir. Arapça kökenli ihsan sözü “iyilik etme, bağışlama ve verilen, bağışlanan şey, lütuf, iyilik" anlamlarında kullanılmaktadır (Develioğlu, 1995: 417). Bekmıradov tarafından tespit edilen Oğuznâme metninin başında yer alan "ve şunu bil ki Ahsan şeyh veya Dânâ Ata üzerine Allah'ın rahmeti olsun ilahi ilhamla dolarak Soyunhan halkına Bu Ŏguzname 'yi hikâye etti' (Демидов, 1976: 166) cümlesi İhsan Şeyh dolayısıyla Dânâ Ata adına işaret etmiştir.

Dânâ Ata Oğuznâmesi (Birkan Akhan, 2017) Türkmen Türkçesinin ağır bastığı Hanlıklar Devri Çağatay Türkçesiyle tespit edilmiştir. Şecere-i Terâkime üzerine çalışan A. N. Samoyloviç, Şecere-i Terâkime'nin çevirmeni Tumanskiy'den "Türkmenlerin Soy Ağacı” adlı eserin Taşkent el yazısının kopyasını almıştır. Bununla birlikte "spiska" şeklinde adlandırılan altıncı listenin de orijinalini de elde etmiştir (Самойлович, 1927: 39-41).

Samoyloviç, Tumanskiy’e ait el yazısını (kopyaladıktan sonra) Tumanskiy’in ölümüyle, Asya Müzesi' (St. Petersburg İlimler Akademisi) ne teslim etmiştir. Mezkûr el yazısının boyutları 18 x 11,5 cm'dir (Самойлович, 1927: 39-41). Dânâ Ata Oğuznâmesi’nin metninin tıpkıbasımı, St. Petersburg İlimler Akademisi Doğu Bilimleri El Yazmaları Bölümü, 1927-no 643 'te, Samoyloviç'in bildirisinde yer almaktadır.

Samoyloviç, mezkûr çalışmasında Dânâ Ata Oğuznâmesi’ne ait şiirin “Tumanskiy’e göre on altı bent sekiz heceli olduğunu belirtmiştir. Hocalı Molla’nın el yazısına göre adı geçen şiir on sekiz bentlidir. Oraz Muhammed Oğlu Molla Gurbangeldi (1237 yılının Recep ayı tarihli), Şecere-i Terâkime'nin (Taşkent nüshası) “perespiçiki” olarak geçmektedir. Oraz Muhammed Oğlu Molla Gurbangeldi'nin adı, hem Ahmed Bekmıradov (Бекмырадов, 1986:184-186) hem de Halik Köroğlu (Короглу,1999: 45) tarafından zikredilmiştir.

Ahmed Bekmıradov, "Edebi Miras Ebedi Miras" adlı eserinin "Dânâ Ata Oğuzname Aydıpdır” makalesinde Dânâ Ata’ya ait iki Kolyazması'nın varlığından bahsetmiştir. Kolyazmalarından biri Türkmenistan'ın Magtımkulu adındaki Dil ve Edebiyat Enstitüsü’nde, Kolyazmalar Bölümü'nün 1771 numarasında saklanmaktadır (Бекмырадов, 1992: 92). Halik Köroğlu ise "Oğuz Kahramanlık Eposu” adlı çalışmasında, Bekmıradov gibi Dânâ Ata’ya 
ait bir Oğuznâme olduğunu bildirmiştir. Ancak Köroğlu, Oğuznâme nüshasının, Oğuznâme adıyla Manuskript archive UBAN altında, Özbekistan SSR.PN185-IV numarada "Og்uznâme ḳ1t’a-1 manzum Dânâ Ata İhsân” şeklinde ve Manuskript archive NHA.inv N 437 numarada kayıtlı olduğunu ifade etmiştir (Короглу, 1999:237).

Bu çalışmada, Dânâ Ata Oğuznâmesi ve Dânâ Ata (İhsan Şeyh) hakkında yapılan çalışmalar tarih sırası dikkate alınarak verilmiştir.

\section{Dânâ Ata Oğuznâmesi hakkında yapılan çalışmalar}

A. N. Samoyloviç, Dânâ Ata (İhsan Şeyh) hakkında ilk bilgiyi, "Ebu'l-Gazi Bahadır Han. Türkmenlerin Soy Ağacı Listelerinden Biri” adlı çalışmasında vermiştir (Самойлович,1927: 39-41). Samoyloviç, “Orta Asya Türk Edebiyatı Materyalleri” adlı eserinin birinci cildinin beşinci ve altıncı sayfalarında da (I, ZVO 19, str 05-06) Dânâ Ata'dan bahsetmektedir (Самойлович, 1927: 39).

Barthold, 12. 1. 1927 tarihinde, Samoyloviç’in mezkûr çalışmasını, "Sovyetler Birliği’nin İlmi Akademi Birliğì” yayınları arasında neşretmiştir (Самойлович, 1927: 39-41). Вildirinin orijinali, ifade edildiği üzere, St. Petersburg İlimler Akademisi Doğu Bilimleri El Yazmaları Bölümü'nde 1927-643 numarada saklanmaktadır. Samoyloviç, çalışmasında, Ebu'l-Gazi Han'ın “Şecere-i Terâkime”sinden küçük bir parçanın, ilk defa, 1908 yılında, Ostromov'un yayımladığı anonim bir yazma olan "İslâm Işı̆̆ı” adlı eserde basıldığını anlatmıştır. Samoyloviç’in “Ostromov’un İslâm Işı̆̆ yazılmıştır:

“İslam Işı̆̆ı adlı eser, Kaspiy (Hazar) bölgesinde ders kitabı olarak okutulur. Buradaki Türkmenler, İslam Işı̆̆ı adlı eserin yazarını Şeyh Şeref olarak bilirler. Aşgabat ilinin Durun ilçesinin sorumlusu Hocalı Molla, 1906'da, İslam Işı̆̆ı eserinin yazarı Şeyh Şeref hakkında bilgi verir" (Самойлович, 2005: 887-895).

Ayrıca, makalenin dipnotunda, Hocalı Molla hakkında şu bilgiler kayıtlıdır:

"Hocalı Molla, akıllı ve çok okumuş bir yaşlıdır. Onun kendi ifadesine göre, kitaplara ve halk rivayetlerine olan sevgisi, kendi ifadesine göre, babasından geçer. Bu sevgi, bizim ilmi çalışmalarımıza kaynak edecek pek çok el yazmaları kazandırdı: Vaaz-ı azad, Magtumkulu'nun babasının Devlet Muhammed'in yazıları ve diğer listelerden farklı olarak Ebu'l-Gazi'nin Şecere-i Terâkimesi ki bu eserle ilgili daha sonra bahsedeceğiz. Ayrıca birçok Türkmen şairlerinin ve onların eserleri hakkında birçok öykü, bütün bunları Hocalı Molla, St. Petersburg'a göndermiştir. 1906 yılında, Molla (1860), sadece, kırk altı yaşında ama aksakal görünümündeydi. Bu makaleyi yazdıktan sonra (1908), biz Hocalı Molla'dan Şecere-i Terâkime'nin listesini aldık ki o listeyi yakın zamanda, Gürgen nehrine Göklenlere yaptığı seyahatten getirdi” (Самойлович, 2005: 887-895).

D. Nuraliyev, 1971 yılında, İlim Neşriyatı'nda, “Akademik A. N. Samoyloviç Türkmen Edebiyatı Hakında” adlı bir eser yayımlamıştır. Çalışmada, Samoyloviç’in hayatı ve bilime katkıları üzerinde durulmaktadır (Нургалиев, 1971: 5-139).

Nuraliyev, Samoyloviç'in bilim hayatına katkıda bulunduğu materyalleri "Gadımı Türkmen Edebiyatı", "XVIII Asır Türkmen Edebiyatı” ve "XIX Asır Türkmen Edebiyatı” şeklin- 
de üç başlık altında toplamıştır. "Gadımı Türkmen Edebiyatı" olarak tanımlanan dönemde, Dânâ Ata (İhsan Şeyh)'nın da adı geçmektedir (Нургалиев, 1971: 31-33). Çalışmada, “İhsan Şeyh'in biyografyasının Türkmen Edebiyatı'nda işlenmediği” anlatılmıştır. Ayrıca, "Dânâ Ata'ya ait eserlerin kaybolduğu" belirtilmiştir. ${ }^{2}$

Samoyloviç, Dânâ Ata'ya ait bilgileri Hocalı Molla'dan almıştır. Onun "Eski Türkmen Şiirleri” adlı eserinde, Dânâ Ata'nın XVI. asırdan önce yaşamadığı anlatılmaktadır. Nuraliyev ise Samoyloviç'in “Asya Türk Edebiyatının Materyalleri” çalışmasına atıfta bulunarak Dânâ Ata Oğuznâmesi'ne ait bilgi vermektedir. Adı geçen Oğuznâme metninin birinci ve son dörtlükleri de verilmiştir (Нургалиев, 1971: 34). Şöyle ki:

“Bu şair, Hocalı Molla el yazmasında karşımıza çıkıyor. Ki bu el yazısında Ebu'l-Gazi’nin değiştirilmiş versiyonu var. Şiirin sonunda, İhsan Şeyh'in ismi var. Yani bu şiir, Oğuz Han'ın oğullarından başlayan Türkmenlerin Soy Ağacı. Şiirden önce Giriş kısmı bulunmaktadır. El Kıssa Gün Han’ın, Oğuz Han'ın eteğinde yayılgan ferzendlerinin atlarının aytalın. İhsan Şeyh, yani Dânâ Ata rahmatılla aleyhesselamdan bolup, Oğuznâme aytıp turur, cemi Seyil Hanga bizden yadıger kalun diyip, anı körüp asıl nesillerini tiyib, bularının şanına nazm kıldilar..." (Нургалиев, 1971: 34).

\section{"Oğuz Handın ayrılmışam \\ Gel Seyil Han ilatımız \\ Bir atadan yayılmışam \\ Yokdur sözde yalanımız}

\section{Pirdir diyirler babamızı}

Nama içre rastdır sözi

Ihsan Baba diyirler bizi

Abulhandır örenimiz" (Нургалиев, 1971: 34).

C. M. Demidov, İlim Neşriyatı'nda yayımlanan Türkmen Evliyaları adlı kitabın ikinci bölümünde "Evliya Topluluklarının Yapısı ve Kökenleri Hakkında Bilgiler” verirken "Şeyh”, "Hoca" ve "Seyit" kavramlarına değinmiştir (Демидов, 1976: 55-175). Eserin "Şeyhler" bölümünün “Kızıl Şeyhler” alt başlığında, Dânâ Ata yani İhsan Şeyh’ten bahsedilmiştir. Hoca Ahmed Yesevî’nin müritleri arasında, Hâkim Ata ile Çolpan Ata'nın isimleri de zikredilmektedir.

Adayevlerin menkıbevî şeceresine göre Çolpan Ata’nın oğulları İhsan Ata, Çagrik (Şahruh) Ata'dır; Tergin Bibi adında da bir kızı bulunmaktadır (Демидов 1976: 89). Aynı eserde, İhsan Şeyh veya Dânâ Ata'nın iki dörtlüğüne de yer verilmiştir (Демидов, 1976: 159). Dörtlüklerin kaynağı olarak A. N. Samoyloviç gösterilmiştir.

Alexandre Bennigsen-S. Enders Vimbush adlı araştırıcılar, 1985 yılında, Muslims of the Soviet Empire: A Guide adlı eserde, Türkmenler arasındaki oymaklardan bahsetmektedirler (Bennigsen, Vimbush,1985, 1986: 98-100). Bennigsen, kitapta, mitik kişiler, ilk kurucular, göçebe boy beyleri ve velilere ait mezar taşları olmak üzere dört tür kutsal ziyaret yeri olduğunu anlatmaktadır (Bennigsen, Vimbush,1985, 1986: 103). Bu mekânlar arasında, Dânâ Ata'nın mezarı da zikredilmektedir. 
Ahmed Bekmıradov, 1986 yılında, Sovet Edebiyatı dergisinde "Dânâ Ata'nın 'Oguzname’ Poeması" adlı bir makale yayımlamıştır (Бекмырадов, 1986: 184-188). Bekmıradov, Samoyloviç’in "Ebu'l Gazi Bahadır Han. Türkmenlerin Soy Ağacı Listelerinden Biri” çalışmasında, Dânâ Ata Oğuznâmesi'ne (Birkan Akhan, 2017) ait teksti yerleştirdiğinden bahsetmiştir. Üçüncü el yazmasının “Oğuznama. Dânâ Ata Ihsan Ata Abulhanı” şeklinde Aşkabat’ta saklandığını belirtmiştir (Бекмырадов, 1986: 185-188).

Ahmed Bekmıradov tarafından İlim Neşriyatı altında yazılan “Andelip Hem Oguznamaçılık Debi” adlı eser, Dânâ Ata hakkında bilgi veren diğer bir çalışmadır. Bekmıradov, ayrıca, XVI asırda başlayan XVIII yüzyılda devam eden Türkmen Edebiyatı'nda "beyan ediliş" üslubunun görüldüğünü de anlatmaktadır (Бекмырадов,1987: 6-11).

Bekmıradov, Dânâ Ata için “Bizin elimizde yene bir 'Oğuznama'var. Ol Dânâ Ata Abı Han değişli. Oğuznamanın bu nüsgasını ilki bilen A. N. Samoyloviç tapıpdır. Gol yazmanı 1821-nci yılda Molla Gurbangeldi Oraz Muhammet Ŏglu göçiripdir" ifadelerini kaydetmiştir (Бекмырадов,1987: 19-20). Himmet Biray tarafindan kaleme alınan "Andelip ve Oğuznâmesi” adlı makalenin Girişinde de Dânâ Ata üzerine çalışma yapan Ahmed Bekmıradov'un adı zikredilmiştir (Biray, 1989: (4),12-32).

Ahmed Bekmıradov, 1992 yılında, ilim dünyasına katkıda bulunduğu makalelerin bir araya getirildiği "Edebi Miras-Ebedi Miras" adlı kitabında, "Dânâ Ata Oğuznama Aydıpdır” başlığında, Dânâ Ata Oğuznâmesi ve Oğuznâmeler hakkında yine bilgi vermektedir (Бекмырадов, 1992: 89-101).

Bekmıradov, Samoyloviç'in bildirisinin adını zikretmeden CCCP’IA-nın Gündoğarı Övreniş Enstitının Golyazmalar Fondı'nın, 2/1927 numarasındaki ile Türkmenistan'ın IA'nın Magtımgulı adındaki Dil ve Edebiyat Enstitüsü'nün Kolyazmalar Fondı'nın 1771-numarasındaki manzum Oğuznâme'nin varlığından haber vermektedir.

Ahmed Bekmıradov, elindeki Kolyazma nüshasının diğer nüshalarla karşılaştırıp şiirin ${ }^{3}$ metninin yayımladığını anlatmıştır. Çalışmada Abdırahman Mulkamanov'un adı da zikredilmektedir (Бекмырадов,1992: 92). Dânâ Ata’ya ait manzum Oğuznâme şöyle verilmiştir:

Oğuz Handan ayrılmuşam

Bil, Söyül Han bolganımız,

Bir atadan yayramuşam

Yokdur sözde yalganımız

Safalıg ak öyün kurd1,

Kirk oğulga orun berdi,

Uzun nama andan erdi,

Yol koyup ötdi Hanımız.

Kün Han oğlı Kay il başı,

Bayat kitür tegre-taşı

Alka öyli berur çaşı

Kara öyli Tarhanımız 
Ay Han oğlı Yazgur, Tüger

Tuturga, Yapur Bahadir

İslamga kirdi köp küfür

Kara daşlı kardaşımız

Yulduz oğlı Kızık Ovşar

Bektil, Karkın hetden aşur,

Küfürler zulmından çaşur

Hızırdır adak Han ilimiz

Hızır ili, Ali ili

Törelerge hizmat k1lu, Hıva, Hazaraspnin gülü

Han aldı da yörgenimiz

Gök Han oğl1 ki Bayundur,

İli baylık-le Çavludur,

Bahadur biçen Çovuldur,

Çebin bile örgenimiz

Tag Han oğl1 Salgur Eymür, Atı Düldül, Kuşı Algur, Alayuntl1, bul Üregir,

Erdür Salgur sorganımız

Teniz Oğlı İgdür, Bükdüz

Uva, Kınık hökmi yalguz

Sahıp Kıran kiçe-kündüz,

Hesen-ili durganımız,

Hesen eli sazlig

Dal bedevlig tebil bazlig, Yügrük at, boynı kotazlıg

Bile kuşlar çapganımız

Altun asarga çi asur

Barur ise ol yev basur

İşi-küçi çalı baş kesur,

Bahadir Alp bu kenimiz

Ülüş aldı on ikisi

Aymak bu sagka bakası

Münge tendir her bökesi,

Her biri Rüstem zalimiz 
Mahbupları kaz boğazlıg,

Yügrük atlıg, eli sazlıg,

Dal bedevlig, tebl bazlig

Bile kuşlar salganımız.

Külli Özbek-Çengiznama,

Kalmuk, Kazak, Kırgız neme,

Astımızga kelse heme,

Yokdur anda durganımız.

Akman, Karaman uruşd1,

Kör, nenen ne kurtlar keçdi,

Oğuz ili zordan köçdi,

$\mathrm{Ol}$ sür-he sür bolganımız

Özün kaldıng yaman atga,

Ömrünin berdin berbetga,

Töhmet kildın Hoca Ahmetge,

Sen-sen yaman körgenimiz.

Sofular1 asıl zatlig,

Pirleri bar keramatlig,

Hocası 1zzat-hormatlig,

İlge duva kılganımız.

Pirdür tiyirler babamıznı,

Nama içre rast tiyir sözin,

Ihsan Baba tiyirler bizni,

Abulhan'dır örgenimiz (Бекмырадов, 1992: 92-94).

Bekmiradov, bu dörtlüklerden sonra "Dânâ Ata'nın yaşan yeri, ömri hem dövri baradaki ilkinci esasırak maglumatları hem şu poemadan alıp bolyar. Bizin elimizde başağa duyupli maglumatlar yok” diyerek manzum Oğuznâme üzerine fikirlerini yazmıştır.

İsa Özkan “Türkmenistan'da Derlenmiş Dede Korkut Boyları” adlı makalede Oğuz Destanlarının kaynakları hakkında bilgi verirken Dânâ Ata Oğuznâmesi'nin adını zikretmiştir (Özkan, 1994). Ayrıca, Zuhal Kargı Ölmez tarafından 1996 yılında hazırlanan "Şecere-i Terâkime" adlı eserde, Samoyloviç hakkında "Samoyloviç tarafindan yazılan şu makalede bu nüshaya ve buradaki manzum parçaya ait kimi bilgiler verilmiştir" ş̧eklinde yazıldığı görülmektedir (Ebu'l-Gazi Bahadır Han (Ölmez), 1996: 26).

C. M. Demidov, 1999 tarihinde, “Türkmen Halklarının Dinî İnançlarının Tarihi” adlı kitabında, Dânâ Ata (İhsan Şeyh) üzerine bilgiler vermiştir. Adı geçen eserin ikinci bölümünde, 
Dânâ Ata, "Mücavirlerin önderi” olarak gösterilmiştir. Demidov’a göre Oğuznâme "Ŏ̆uz Han'ın ve onun soyundan gelenler hakkındaki hikâyelerin, manzum, edebi ve tarihi sunumudur" (Демидов, 1990: 115-118).

Halil Köroğlu, 1999 yılında, “Oğuz Kahramanlık Eposu” adlı kitabının “Mitler, Efsaneler ve Rivayetler” bölümünde, Doğudaki Oğuzlardan bahsetmektedir. Mezkûr bölümde, Ebu'lGazi Bahadır Han'ın eserine benzer iki Oğuznâme adını zikretmiştir. Oğuznâmelerden biri St. Petersburg İlimler Akademisi'nin El Yazmaları Bölümü’nde saklanan Dânâ Ata (İhsan Şeyh)'e ait Dânâ Ata Oğuznâmesi'dir (Короглy, a. g. e. 44-45).

Halil Köroğlu, manzum Oğuznâme'nin Kayı boyunun Çarıg uruğuna mensup Oraz Muhammed Gurbangeldi (1237/1821) tarafından yazıya geçirildiğini ifade etmiştir. Bununla birlikte, el yazmasının on üçüncü sayfasında, bu kitaba "Şecere-i Türk” denildiğini kaydetmektedir. Köroğlu, Dânâ Ata Oğuznâmesi’nin Ebu'l Gazi Bahadır Han’ın iki Oğuznâmesi’nden izler taşıdığını bildirmiştir (Birkan Akhan, 2017). Bu cümleden Türkmen araştırıcı Dânâ Ata Oğuznâmesi'ne ait metnin değiştirildiği kanaatindedir. ${ }^{4}$

Yusuf Akgül tarafindan 1999 yılında kaleme alınan "Hoca Ahmet Yesevî̀nin Hazar Ötesi Türkmenlerine Tesiri ve Bu Çerçevede Bazı Tesbitler" adlı makalede, Dânâ Ata ile Hoca Ahmed Yesevî arasındaki ilişki, Dânâ Ata Oğuznâmesi’ne ait dörtlüklerle açıklanmak istenmiştir (Akgül, 48-61). Akgül, Türkmenistan'da "Evliya” olarak kabul edilen türbe ve mezarlıklarda Dânâ Ata'nın da adını zikretmektedir. Ayrıca Oğuznâme metnindeki dörtlüklerden yola çıkarak Ahmed Yesevî ile Akman-Karaman boyları arasındaki münasebete de değinmiştir (Akgül, 1999).

Kitab-1 Dede Korkut Ansiklopedisi’nin “Oğuznâmeler” başlığı altında yine Dânâ Ata Oğuznâmesi'nden bahsedilmektedir. Dânâ Ata Oğuznâmesi, hece vezninde yazılmış ilk manzum Oğuznâme olarak gösterilmiştir. Çalışmaya göre, XV. Yüzyılın ikinci yarısı ile XVI asrın başında yaşadığı düşünülen Dânâ Ata'nın tarikat silsilesi Ahmet Yesevî’ye dayandırılmıştır. Ayrıca, Oğuznâme'nin Türkmen Evliya tayfalarından Mücavirlerin atası Dânâ Ata tarafından söylenildiği ifade edilmiştir (Kitab-1 Dədə Qorqud Ansiklopedyası, 2000).

Fuzuli Bayat 2006 yılında hazırladığı “Oğuz Destan Dünyası” adlı eserde, Dânâ Ata Oğuznâmesi'ni, “Oğuz Destanı ve Onun Araştırılma İcmali” alt başlığı altında ele almıştır. Bayat, Dânâ Ata'nın ölüm tarihini 1608 yılı olarak göstermiştir. Oğuznâme’nin adını da "Dânâ Ata Abı Han Oğuznâmesi" şeklinde ifade etmiştir. Çalışmada, Dânâ Ata Oğuznâmesi, Oğuznâmecilik geleneğinde hece vezniyle yazılan ilk şiir şeklinde tanıtılmıştır. Oğuznâme'nin iki dörtlüğü verilerek on sekiz bentlik sekiz heceli şiir olduğu vurgulanmıştır (Bayat, 2006: 26-27).

Murat İlliyev tarafindan 2010 yılında "Türk Tarihinde Şecere Geleneği: Türkmen Şecereleri Örneği” adlı Doktora tezi hazırlanmıştır. Çalışmada, Evliya kültünden de bahsedilmektedir. İlliyev, Türkmenlerin ziyaret için türbe ve kabirlere giderek Allah rızası için dua ettiklerini anlatmaktadır. Ziyaret yerleri arasında Dânâ Ata ile birlikte Saras Baba, İdris Baba, Necmedddin Kübra, Ağışan, Gürcü Ata, Hâkim Ata, Astana Baba, Ebu Sait Meyhemi gibi evliyaların adları zikredilmektedir (Birkan Akhan, 2017). Dânâ Ata'nın ziyaret yeri Balkan vilayetinde Ala aşireti bölgesinde gösterilmiştir (İlliyev, 2010). 
İhsan Kalenderoğlu'nun 2010 yılında yazdığı “A. N. Samoyloviç’in Türkmen Edebiyatı ve Folkloru Araştırmalarına Katkıları” adlı makale, Dânâ Ata Oğuznâmesi hakkında bilgi veren diğer bir çalışmadır. Kalenderoğlu, Samoyloviç'in Hocalı Molla'dan aldığı materyaller doğrultusunda, Türkmen Goroğlu Destanı ve Dânâ Ata Oğuznâmesi’yle ilgili çalışmalar yaptığını yazmıştır (Kalenderoğlu, 2010). Bu veriler, adları zikredilen Nuraliyev ve Bekmıradov'a dayandırılmıştır.

Mustafa Aça, "Oğuznâmecilik Geleneği ve Andelip Oğuznâmesi”" adlı çalışmanın "Yazılı ve Tarihi Kaynaklarda Oğuz Kağan Destanı” alt başlığında Dânâ Ata Oğuznâmesi’nden söz etmektedir (Aça, 2011: 16).

Muratgeldi Söyegov, Dânâ Ata Oğuznâmesi üzerine çalışan bir diğer araştırıcıdır. Söyegov, 2012 yılında, Kardeşlik Kültür ve Edebiyat Dergisi’nde "Çăgatayca Bir Şiir Olarak Oğuznâme" adlı bir makale yazmıştır. Oğuznâme metnini Latin harflerine aktararak yayına hazırladığını ifade etmektedir. Ancak, Dânâ Ata Oğuznâmesi’ne ait metnin kaynakçası gösterilmemiştir. Makalenin Giriş kısmı şöyledir:

“Alman asıllı meşhur Rus Türkolog Wilhem Barthold’un (1869-1930) 'Türk halklarının arasında sadece Türkmenler kendi tarihlerinden bahseden eski kitap ('Oğuznâme') sahipleridir." sözleri XX. yüzyılın başlarından itibaren uzmanlarca belirlendi. Ancak şunu önemle ifade etmeliyiz ki nesirle tespit edilmiş pek çok büyük 'Oğuznâme' nüshalarının yanı sıra, eski şairlerimiz tarafından şiirle meydana getirilmiş mühim 'Oğuznâmeler' de vardır. Onlardan, henüz az bilinen şairimiz Abulhanlı (Türkmenistan, Balkan vilayeti) Dânâ Ata (Baba) İhsanî'nin XVII yüzyılda kullanılan yazı dili Çağatayca ile kaleme aldığı bir 'Oğuznâme'yi okuyucularımızın dikkatine sunuyoruz" (Söyegov, 2012).

İsa Özkan 2014 yılında, V. Uluslararası Türkiyat Araştırmaları Sempozyumu' (Oğuzlar: Dilleri, Tarihleri ve Kültürleri) nda "Hazihi'r-Risâlet-i Min Kelimât-1 Oğuznâme El-Meşhur Bi-Atalar Sözü" adlı bir bildiri sunmuştur. Çalışmada, "Muhtevası, kahramanları ve az çok konusu bakımından birbirini tamamlayan on Ŏguznâme'nin" varlığından söz edilmiştir. Bu Oğuznâmelerden biri de Dânâ Ata Oğuznâmesi'dir (Özkan, 2015).

Muratgeldi Söyegov, Akademik Bakış Dergisi’nde "Eski Türkmence Şiir Olarak İki 'Oğuznâme' Metni ve Yazarları” adlı bir makale yazmıştır. Çalışmasında, Dânâ Ata Oğuznâmesi ile Andelip Oğuznâmesi'ne ait metinler vermiştir. Söyegov, Dânâ Ata’ya ait Oğuznâme metninin kaynakçasına Türkmenistan İlimler Akademisi'ne bağlı Milli Elyazmalar Enstitüsü'ndeki 1771 sayılı Envanteri göstermiştir (Söyegov, 2014). Söyegov'un makalesindeki Dânâ Ata Oğuznâmesi’ne ait metinle, daha önce yayımlanan Kardeşlik Kültür ve Edebiyat Dergisi'ndeki tekstin aynı olduğu dikkat çekicidir (Birkan Akhan, 2017). Ayrıca, Dânâ Ata Oğuznâmesi'ne ait metinlerin Ahmed Bekmıradov'un ilim dünyasına tanıttığı şiir ile aynı olduğu görülmektedir (Бекмырадов, 1992: 92-94).

Ramiz Asker, 2015 yılında "Kardeş Kalemler” dergisinde, "350 yıllır Şakıyan Bülbül” başlığı altında Dânâ Ata Oğuznâmesi'nden bahseden diğer bir ilim adamıdır. Asker, Dânâ Ata Oğuznâmesi'nin XVI. yüzyılda yazılabileceğini ifade etmiştir (Asker, 2015). 


\section{Sonuç}

Türkmenlerce Dânâ Ata Oğuznâmesi’nin müellifi olduğu söylenilen Dânâ Ata' (İhsan Şeyh) nın devrinin bileni, bilicisi olduğu görülmektedir. DânâAta, devrinin Dede Korkut'udur; İslâmî ortamda Ata kimliğine bürünmüş yaşlı bir bilge derviştir. Ayrıca Oğuznâme metninden de anlaşıldığı üzere, Dânâ Ata'nın Hoca Ahmed Yesevî’ye bağlı olduğunu ifade etmiştir.

Dânâ Ata Oğuznâmesi hakkında ilk bilgiyi, Samoyloviç, "Ebu'l-Gazi Bahadır Han. Türkmenlerin Soy Ağacı Listelerinden Biri” adlı çalışmasında vermiştir. Barthold, 12. 1. 1927 tarihinde, Samoyloviç'in bildirisini "Sovyetler Birliği’nin İlmi Akademi Birliği” yayınları arasında neşretmiştir. Mezkûr bildirinin orijinali St. Petersburg İlimler Akademisi Doğu Bilimleri El Yazmaları Bölümü'nde 1927-643 numarada saklanmaktadır. Samoyloviç'in bildirisinden elde edilen bilgilere göre, Dânâ Ata Oğuznâmesi'nin Hocalı Molla ve Oraz Muhammed oğlu Molla Gurbangeldi adlarında iki yazıya geçireni bulunmaktadır. Veriler doğrultusunda, St. Petersburg İlimler Akademisi'ndeki Dânâ Ata Oğuznâmesi'ne ait metnin daha önce yazıya geçirildiği düşünülebilir. Ayrıca, manzum Oğuznâme'nin Özbekistan ile Türkmenistan'da iki nüshasının daha olduğu anlaşılmaktadır.

Oğuznâmecilik, Oğuznâmelerin dilden dile nesilden nesile aktarıldığını ifade eden bir gelenektir. Bu durumda Dânâ Ata Oğuznâmesi'nin de sözlü gelenekte icra edildiği ve zamanla yazılı geleneğe aktarıldığg göz ardı edilmemelidir.

\section{Notlar}

1. Oğuznâme için bakınız: Orkun, H. N. (1935). Oğuzlara Dair. Ankara: Ulus Basımevi, 77.; Bang, W., Rahmeti, G. R. (1970). Oğuz Kağan Destanı. İstanbul: Milli Eğitim Basımevi. (Eserin orijinali 1936 yılında basılmıştır), 1-29.; Köprülü, M. F. (1981). Türk Edebiyatı’nda Illk Mutasavviflar. (Dördüncü Basım). Ankara: Diyanet İşleri Başkanlığı Yayınları, 247-255.; Reşidüddin, F. (1982). Oğuz Destanı, Reşidüddin Oğuznâmesi, tercüme, tahlil. (Hazırlayan: Zeki Velidî Togan). (İkinci Baskı). İstanbul: Enderun, 13-162.; Ercilasun, A. B. (2007). Makaleler, Dil-Destan-Tarih-Edebiyat. (Yayına Hazırlayan Ekrem Arıkoğlu). Ankara: Akçağ,449-453.; Gökyay, O. G. (2006). Dedem Korkudun Kitabı. (Birinci Basım). İstanbul: Kabalcı Yayınevi, 701.; Alizade, S. (2006). Oğuzname. Azerbaycan: Şark-Garb, 5.; Ali Emiri Efendi. Cam-ı Cemâyin. Millet Genel Kütüphanesi, Eski Kayıt No: 203, 3-7.; Ebu’l Gazi Bahadır Han. (1996). Şecere-i Terâkime. (Hazırlayan: Zuhal Kargı Ölmez). Ankara: Simurg, 222.; Güler, M. (2010). Salar Baba Oğuznâmesi. (İnceleme, Metin, Tercüme, Dizin). Yayımlanmamış Yüksek Lisans Tezi, Ankara Üniversitesi, Sosyal Bilimler Enstitüsü, Ankara.; Özkan, İ. (2015). Hazihi'r-risalet-i min kelimât-1 Oğuznâme el-meşhur bi-atalar sözü. Hacettepe Üniversitesi Türkiyat Araştırmaları Enstitüsü, Oğuzlar. Dilleri, Tarihleri ve Kültürleri, 343-350.; Самойлович, А. Н. (1927). Один из списков «Родословного древа туркменского» Абуль гази-хана. Доклад Академии Наук СССР, 39-41.; Rıdvan N. (1934). "Oğuz Destanından Bir Parça”. Türk Tarih Arkeologya ve Etnografya Dergisi. II, 243-249.

2. “Onun eserlerinen hem nüsgalar golyazmalar fondunda yok denilmektedir" (Нургалиев, 1971: 33).

3. "Biz elimizde var olan Kolyazma nüshaları deneştirip, övrenip poemenın tekstini tayyarladık. Şu işde, özümüze yakından kömek veren tekstolog alım Abdirahman Mulkamanov'a ulı minnettarllk aydasim gelyer. Makalamızda şol kiçicik poemanın dolulığına getirmeği makul gördük”" (Бекмырадов, 1992, 92).

4. “Tamamıyla aydındır ki, söyleci (veya katib) Dânâ Ata Ebu'l Gazi'nin metnini tahrip etmişstir. El yazmada metinden kanaraçıhmalar çohdur” (Короглу 1999, 45). 


\section{Kaynaklar}

Aça, M. (2011). Ŏguznamecilik geleneği ve Andalıp Oğuznamesi. (Genişletilmiş ikinci baskı). Kömen, $16-219$.

Akgül, Y. (1999). Hoca Ahmet Yesevî’nin Hazar ötesi Türkmenlerine tesiri ve çerçevede bazı tespitler. bilig, (8/Kış), 48-61.

Asker, R. (2015). 350 yıldır Şakıyan Bülbül. Kardeş Kalemler dergisi. (İnternet: www.kardeskalemler. com/haziran2011/350_yildir_sakiyan_bülbül.htm. (22.05 2015'te alınmıştır.)

Bayat, F. (2006). Oğuz Destan Dünyası, Oğuznâmeleri tarihi, mitolojik kökenleri ve teşekkülü. İstanbul: Ötüken, 25-27.

Бекмырадов, А. (1986), Дана Атанын Огузнама Поэмасы. Журнал советской литературы, 185-188.

Бекмырадов, А. (1987). Андемир Хем Огузнамачылык Деби. Ашхабад: Илим, 6-127.

Бекмырадов, А. (1992). Эдеби мирас эбеди мирас. Ашхабад: Туркменистан. Ричы, 151.

Bennigsen, A., Vimbush, S. E. (1985, 1986). Muslims of the Empire: a guide, London: Hurst, 92-104.

Biray, H. (1989). Andelip Oğuznamesi, I-II-III. Milli Folklor, (4), (5), (6), 12-32, 23-24, 21-23.

Birkan Akhan, E. (2017). Dânâ Ata Oğuznâmesi ve Oğuznâmecilik geleneği. Yayımlanmamış Doktora Tezi, Gazi Üniversitesi Sosyal Bilimler Enstitüsü, Türk Dili ve Edebiyatı Ana Bilim Dalı, Ankara.

Самойлович, А. Н. (1927). Один из списков «Родословного туркменского». Абуль гази-хана. Доклад Академии Наук СССР,39-41.

Самойлович, А. Н. (2005). Тюркское языкознание. Филология. Руника. Восточная литература PAH, 887-895.

Демидов, С. М. (1976). Туркменские овляды. Ашхабад: Ылым, 55-183.

Демидов, С. М. (1990). История религиозных верований народов Туркменистана. Ылым, 115-164.

Develioğlu, F. (1995). Osmanlıca, Türkçe ansiklopedik lûgat. (Genişletilmiş On ikinci Baskı). Ankara: Aydın, 164-417-982.

Ebu'l Gazi Bahadır Han. (1996). Şecere-i Terâkime. (Hazırlayan: Z. K. Ölmez). Ankara: Simurg, 22-269.

Ergin, M. (1997). Dede Korkut kitabı (Giriş, Metin, Faksimile). (Dördüncü Baskı). Ankara: Türk Dil Kurumu, 4-169.

Hoppal, M. (2012). Avrasya'da Şamanlar. (Çev. B. Bayram, H. Ş. Çağatay Çapraz). İstanbul: Yapı Kredi. (Eserin orijinali 2005 yılında basılmıştır), 19-63.

Нургалиев, Д. (1971). Академик $A$. Н Самойлович $O$. туркменской литературе. Ашхабад: Илим, 5-139.

İlliyev, M. (2010). Türkmen şecereleri geleneği: Türkmen şecereleri örneği, Yayımlanmamış Doktora Tezi, Ankara Üniversitesi Sosyal Bilimler Enstitüsü, Ankara.

Kalenderoğlu, İ. (2010). A. N. Samoyloviç'in Türkmen edebiyatı ve folkloru araştırmalarına katkıları. Gazi Türkiyat, (6), 289.

Kitab-ı Dadə Qorqud ansiklopedyası. (2000). Bakı: Yeni Neşrler Evi.

Короглу, Х. (1999). Огуз кахраманлыг эпосу. Баку: Юрт,3-238.

Özkan, İ. (1994). Türkmenistan'da derlenmiş Dede Korkut boyları. Türk Dili Araştırmaları Yıllı̆̆gBelleten, 263-314.

Özkan, İ. (2015). Hazihi'r-risalet-i min kelimât-1 Oğuznâme el-meşhur bi-atalar sözü. Hacettepe Üniversitesi Türkiyat Araştırmaları Enstitüsü, Ŏguzlar. Dilleri, Tarihleri ve Kültürleri, 343-350.

Söyegov, M. (2012). Çağatayca bir şiir olarak Oğuzname. Kardeşlik Kültür ve Sanat Dergisi. (275276), 21-22.

Söyegov, M. (2014). Eski Türkmence şiir olarak iki 'Oğuznâme' metni ve yazarları. Akademik Bakış Dergisi, Uluslararası Hakemli Sosyal Bilimler Dergisi E Dergisi, (40). 